\title{
İstanbul'daki Afrikalı Göçmenlerin Gündelik Irkçılık Deneyimleri
}

\section{Doğuş Şimşek ${ }^{1}$}

Öz: Bu makale, İstanbul'daki Afrikalı göçmenlerin deneyimleri üzerinden 'gündelik ırkçılık' kavramına odaklanarak ırkçılığın gündelik pratikler bağlamında nasıl oluşturulduğunu, güçlendirildiğini ve gündelik ırkçılığın İstanbul'da Afrikalı göçmenlerin yaşamlarına etkilerini incelemeyi amaçlamaktadır. Etnografik saha çalışması kapsamında istanbul'da yaşayan 50 Afrikalı göçmen ile derinlemesine yüz yüze görüşmeler yapılarak Afrikalı göçmenlerin "gündelik ırkçılık" deneyimleri ve yaşamlarına olası etkileri araştırılmıştır. Bu çalışmada, "gündelik ırkçıllığın", gruplar arasındaki güç ilişkilerinde kendisini gösterdiği ve yapısal eşitsizliklerin, gündelik deneyimler ve etkileşimler yoluyla pekiştirildiği savunulmaktadır.

Anahtar Kelimeler: Afrikalı Göçmenler, İstanbul, Gündelik Irkçılık, Göç

\section{The Experiences of Everyday Racism against African Migrants in Istanbul}

Abstract: This paper focuses on 'everyday racism' as a new form of racism against African migrants in Istanbul and aims to examine how racism is created and reinforced through everyday practices, and what the impacts of everyday racism are on the daily lives of African migrants in Istanbul. Drawing on ethnographic fieldwork- in-depth interviews with 50 African migrants- in Istanbul, the processes of 'everyday racism' against African migrants and the experiences of everyday racism among African migrants are explored. It is argued that 'everyday racism' exists within the structure of group power, and structural inequalities are reinforced through everyday practices and interactions.

Keywords: African migrants, Istanbul, Everyday Racism, Migration

\footnotetext{
Dr., Koç Üniversitesi, İnsani Bilimler ve Edebiyat Fakültesi, e-posta: dsimsek@ku.edu.tr, Orcid: https://orcid.org/0000-0002-8025-5390
} 


\section{Giriş}

Bu makale, İstanbul'da yaşayan Afrikalı göçmenlerin ırkçılık deneyimlerini açıklarken "gündelik ırkçılık" kavramını teorik bir temel olarak uygulamaktadır. Essed (1991), 'gündelik ırkçılık' kavramını gündelik yaşamın sistematik, tekrarlayan, bilinen uygulamaları olarak tanımlayarak genelleştirilebilen, sosyalleşmiş tutum ve davranışları içeren, deneyimlerle ilgili olan ve toplumun her kademesinde uygulamaların tutarlılığını gösteren uygulamalardan oluştuğu vurgulamaktadır. Bu makalede, "gündelik ırkçılık", gündelik yaşamdaki sosyal ilişkilerde, toplumun tüm seviyelerindeki toplumsal ilişkilerde ortaya çıkan, yapısal güçlüklerin gündelik uygulamalar ve etkileşimlerle güçlendirildiği grup hiyerarşik yapısı içinde ortaya çıkan sistematik deneyimler olarak tanımlanmaktadır. Bu makalede, "gündelik ırkçılığın” gruplar arasındaki güç ilişkilerinde kendisini gösterdiği ve yapısal eşitsizliklerin, gündelik deneyimler ve etkileşimler yoluyla pekiştirildiği savunulmaktadır.

Makale birbiriyle ilişkili dört kısımdan oluşmaktadır. Birinci kısımda, ırkçılığa ve günlük ırkçılığa odaklanan teorik çerçeve incelenmiştir. Ikinci kısım, araştırmanın yöntemlerini sunmaktadır. Üçüncü kısım, Türkiye'deki Afrikalı göçmenlerin yaşamlarına genel bakışı açıklamaktadır. Dördüncü kısım, ampirik veriler bağlamında İstanbul'daki Afrikalı göçmenlerin gündelik ırkçılık deneyimleri hakkında fikir vermektedir. Sonuç kısmında ise araştırmanın kilit bulguları teorik çerçeve kapsamında tartışılmaktadır.

\section{Teorik Çerçeve: “Gündelik Irkçılık”}

Irkçılığın tanımı tarih boyunca değişmiştir. 1960'larda ırkçıık, azınlık ve çoğunluk toplulukları arasındaki ırkçı kategoriler temelinde toplumsal ilişkilere odaklanmıştır (Rex, 1973; Banton, 1979), 1980'lerde ırkçוlık, neo-Marksist bir bakış açısıyla sınıf ve ideoloji ile ilgili olarak tanımlanmıştır (Rex 1973; Miles 1989). 1990'larda, ırkçılığı sınıftan ziyade kimlik, kültür, etnik köken, yerellik ve milliyetçilikle ilgili tanımlayan bir tartışma ortaya çıkmıştır (Back 2001; Castles 1993; Castles vd., 1973; Cornell ve Hartmann 2007; Essed 1993; Gilroy 1987; Goldberg, 1990, 2005; Solomos ve Back 2001; Vasta 1993; Wrench ve Solomos 1993). Ayrıca ırkçılık, Essed'in savunduğu gibi yapı ve süreçle ilişkilendirilmiş ve “daha geniş sosyal yapıdaki doğal eşitsizlikler, belirleyici bir şekilde, "ırk” veya "etnik" olarak farklı görülenlere atfedilen biyolojik ve kültürel faktörlerle ilişkilidir” şeklinde tanımlanmıştır (Essed 1991: 43). Buna paralel olarak bu makalede ırkçılık kavramı, göç alan toplum bireylerinin Türkiye'deki Afrikalı göçmenlere karşı ırkçı tutumlarını ırk, kültür ve sosyo-ekonomik faktörlere dayanarak karakterize etmek için kullanılmaktadır.

Irkçוlık ve göç konusundaki çalışmalar çoğunlukla kurumsal ırkçוlık, hükümetlerin göçmenlere eşit davranmaması, göç politikalarında göçmenlerin ırklaştırılması, kültürel ırkçılık, gündelik ırkçılık, çok kültürlülük ve entegrasyon gibi konulara odaklanmaktadır (Brubaker 1990; Erel, Murji ve Nahaboo 2016; 
Schuster 2003; Solomos 1989). Irkçılık ve göç konusundaki çalışmaların çoğu, göç politikalarının göçmenlere karşı ırkçılığın ana itici gücü olduğunu vurgulamaktadır. Ancak, göçmenlere hükümet politikalarından bağımsız olarak oluşan ırkçılığın inşası konusunda az araştırma yapılmıştır.

Afrikalı göçmenler ve göç alan toplum bireyleri arasında gündelik yaşamda mikro düzeyde etkileşimler, ırkçılığın gündelik yaşamda nasıl yaratıldığını ve güçlendirildiğini anlamak için bir başlangıç noktası olarak kullanılmaktadır. 'Gündelik yaşam', bu makalede bireylerin gündelik yaşamlarındaki sosyal ilişkiler ve olayları kapsamaktadır. 'Gündelik yaşam' kavramının tanımlanışının, bireylerin sosyal ilişkilerde konumlarının aynı olmadığı göz önünde bulundurularak farklııık gösterdiği belirtilmiştir. Essed'in "gündelik yaşamdaki etkileşimler, hiyerarşik bir şekilde ırk, etnik köken, sınıf ve cinsiyet ilişkileriyle yapılandıııldığında gündelik ırkçılık kavramını ortaya koyar" şeklinde tanımladığı "günlük ırkçılık" teorisi (Essed 1991: 49), bu makalede gruplar ve bireyler arası etkileşimlerin analizinde kullanılacaktır. Essed'in teorisi her günü bir başlangıç noktası olarak ele almakta, bireyden ziyade uygulamalara odaklanır ve sosyal ilişkileri gündelik yaşamın yapısını temsil eden bir etmen olarak değerlendirmektedir (Hallgren 2005: 321).

Irkçılık, yalnızca ideoloji ve yapı ile ilgili değil aynı zamanda gündelik yaşamdaki rutin durumlarla ilgili pratikler ve deneyimler ile de ilgilidir. Irkçlık, bu çalışmada baskın grup ile azınlık gruplar arasında önyargılar, görüşler ve deneyimlerle şekillendirilen tutumlar, gündelik etkileşimler ve ayrımcı söylemler gibi sosyal pratikler içinde görülebilen mikro düzeyde güç ilişkileri biçimi olarak tanımlanmıştır. Bu anlamda "gündelik ırkçılık, ırkçılığın ideolojik boyutlarını günlük davranışlarla ilişkilendirir ve ırkçılığın yapısal güçlerini günlük yaşamdaki deneyimlerle birleştirir" (Essed 1991: 2). Essed'in gündelik ırkçlık teorisi dikkate alındığında, bu makale göç alan toplum bireyleri ile Afrikalı göçmenler arasındaki güç ilişkilerine, sosyal ilişkilere ve tutumlarını etkileyebilecek konulara odaklanmaktadır.

Giddens (1981: 66), bireylerin ırkçlığa neden olabilecek yapısal ırksal eşitsizlikleri yeniden yaratmak için sosyal pratikleri kullandığı bir sistem olarak sosyal ilişkileri, "düzenli sosyal pratikler olarak organize edilen, aktörler veya kolektif gruplar arasında yeniden üretilen ilişkiler" şeklinde tanımlanmaktadır. Başka bir deyişle bireyler, sistemi yapısal faktörlerin amacı olmadan ırkçılık oluşturmak için kullanabilirler. Bu makalede gündelik ırkçılığın toplumda Afrikalı göçmenlere karşı oluşumu, ideolojiler, gündelik pratikler içinde var olan güç ve sosyal yapılar, toplumda değişen sosyal, ekonomik ve politik koşullara uyum sağlayan düzenlemeler ve kaynaklara erişim (Essed 1991, 2002) gibi geniş bir yelpazede analiz edilmektedir.

\section{Metod}

Bu çalışmada sunulan veriler İstanbul'da yaşayan 50 Afrikalı göçmen ile yarı yapılandırılmış yüz yüze derinlemesine görüşmeler yapılarak elde edilmiştir. 
Görüşülen Afrikalı göçmenler 19 ila 44 yaşları arasındaki 27 erkek ve 23 kadından oluşmaktadır ve 15 katılımcı dışında çoğu düşük gelir profiline sahiptir. Türkiye'de kalış süresi katılımcılar arasında değişmektedir. Bazı katılımcılar altı ay önce Türkiye'ye göç ederken diğerleri birkaç yıldır Türkiye'de yaşamaktadır.

Araştırma kapsamında görüşülen Afrikalı göçmenleri seçerken geldikleri ülkelerin çeşitliğinin yanı sıra cinsiyet, yaş dağılımı, inanç farklılıkları ve ekonomik olarak farklı sınıflara mensup olmalarına da önem verilmiştir. Nijerya, Demokratik Kongo Cumhuriyeti, Senegal, Somali, Gana ve Etiyopya'dan gelen, kadın, erkek, Hristiyan, Müslüman, kargo işletmecisi, restoran sahibi, kuaför, futbolcu, futbol antrenörü, papaz, aktör, tekstil atölyelerinde çalışan Afrikalılar ile kiliselerde, futbol sahasında, kargo işletmelerinde, işlettikleri restoranlarda, kuaför salonlarında ve kafelerde görüşüldü. Katılımcıları çeşitli gruplardan seçerek, cinsiyet, sınıf, din ve göçmen statülerinin günlük ırkçılığın deneyimleri üzerinde önemli bir rol oynayıp oynamadığını araştırmak hedeflenmiştir.

Araştırma kapsamında görüşülen Afrikalı göçmenlerin çoğu, Türkiye’ye Avrupa'ya gitmek için geldiklerini, geçiş sürecini Türkiye'de çalışarak geçirdiklerini fakat Avrupa'ya gidiş yolu pahalı ve tehlikeli olduğu için gidemediklerini ve uzun süre Türkiye'de yaşamak zorunda kaldıklarını söylediler. Ayrıca birikimlerinin çoğunu göç yolunda harcadıkları ve uzun yıllar ülkelerine geri dönemedikleri için İstanbul'da kurdukları sosyal ağlar yardımıyla iş bulup çalışarak ülkelerindeki ailelerine para göndermeyi istediklerini ifade ettiler.

Görüşülen Afrikalıların büyük kısmı Türkiye’ye turist vizesi ile giriş yaptıktan sonra vizelerini yenilemeyerek 'düzensiz göçmen' durumunda olsa da aralarında ikameti ve çalışma izni olan, öğrenci vizesi ile Türkiye'de eğitimine devam eden ve Türkiye Cumhuriyeti vatandaşı ile evlenenler de mevcut. Araştırmanın saha çalışması, Kumkapı, Dolapdere ve Tarlabaşı'nda gerçekleşmiştir. Afrikalı göçmenlere işlettikleri kargo dükkanları, kuaför salonları ve restoranlar aracılığı ile ulaşılmıştır. Görüşmelerin çoğu İngilizce yapılmıştır ve her görüşme yaklaşık bir saat sürmüştür. Araştırmaya katılan kişilerden aydınlatılmış onam alınmıştır ve tüm katılımcıların kimlikleri gizli tutulmuştur. Her görüşme sırasında ses kaydı alınmamıştır. Görüşmeler sırasında ses kaydı alınmasını isteyen kişiler ile yapılan görüşmelerin ses kaydı alınmıştır. Görüşme soruları katılımcıların kendi deneyimleri hakkında konuşmasına izin vermek için mümkün olduğunca 'açık' olacak şekilde tasarlanmıştır. Afrikalı göçmenlere sorulan sorular, iş yerinde, mahallede, okulda ve sokakta yani gündelik yaşamın her alanında göç alan toplum bireyleri ile kurulan ilişkilere ve haklara erişim süreçlerine odaklanmıştır. Araştırma verileri, NVIVO nitel veri analizi programı ile tematik çerçeveye göre ayrıştırılarak analiz edilmiştir.

Araştırma özellikle düzensiz göçmen statülerinden dolayı ulaşılması zor bir katılımcı grubu ile gerçekleşmiştir. Katılımcıların güvenlerini kazanmak için uzun süre sosyal alanlarında; işlettikleri, çalıştıkları restoranlarda, kafelerde ve 
kiliselerde onlarla birlikte zaman geçirilmiştir ve sonrasında yüz yüze derinlemesine görüşmeler yapılmıştır.

\section{Türkiye'deki Afrikalı Göçmenler}

1980'lerin sonlarından bu yana- 1990'ların başında, çeşitli Afrika ülkelerinden artan sayıda göçmen Türkiye'ye gelmiştir (Brewer ve Deniz, 2006: 6). Gana, Kongo, Etiyopya, Eritre, Kenya, Sudan, Nijerya, Somali gibi çeşitli Afrika ülkelerinden Türkiye'ye göç etmektedirler. Sahra-Altı Afrika ülkelerinden gelen göçmenlerin sayısının özellikle 1990'ların sonundan itibaren hızla arttığı birçok araştırmada belirtilmiştir (Coşkun 2016; Özdil 2008; Brewer ve Yükseker 2006; Baird 2011; Şaul 2013; De Clerck 2013). Türkiye'de yaşayan Afrikalı göçmenlerin sayıları tam olarak bilinmemekle birlikte özellikle 2000'li yıllarda gerçekleşen göçler ile sayılarındaki artış dikkat çekmektedir. Özellikle 2005 yılından itibaren Afrika ülkeleri ile Türkiye arasında gelişen ticaret ilişkileri ve iş birliği nedeniyle Türkiye'deki Afrikalı göçmenlerin sayısı artmaktadır (Özkan ve Akgün 2010). Resmi verilere göre, Türkiye'deki 2017 itibariyle yaklaşık 1,5 milyon Afrikalı göçmen bulunmaktadır ve çoğu İstanbul'da ikamet etmektedir. ${ }^{2}$ istanbul'daki Senegalliler en büyük Sahra altı göçmen grubunu oluştururken; ikinci en büyük grup ise Nijeryalılardır (Şaul, 2013). İstanbul'daki Afrikalı göçmenlerin çoğu, Sahra-altı Afrika, Batı Afrika (Nijerya, Moritanya, Senegal, Gana), Orta Afrika (Demokratik Kongo Cumhuriyeti), Doğu Afrika (Somali, Etiyopya, Eritre, Ruanda), Kuzey Afrika (Fas, Tunus, Cezayir ve Libya) ülkelerinden göç etmektedirler. Daha çok genç ve orta yaş grubundan olan Afrikalıların demografik dağılımları göçmen statülerindeki çeşitlilik nedeniyle bilinmese de bireysel göçlerin yanı sıra ailelerin göçü de görülmektedir.

Türkiye'deki Afrikalı göçmenlerin göç nedenleri çeşitlilik göstermektedir ve genellikle ülkelerindeki çatışmalar, ekonomik zorluklar, yoksulluk, eğitim ve transit göç gibi farklı nedenlere dayanmaktadır. Batı ve Orta Afrika'dan gelen göçmenler daha çok ekonomik nedenlerden dolayı göç ederken Doğu Afrikalılar sığınmacı olarak gelmektedir (Brewer ve Yükseler, 2006). Afrikalı göçmenler, sığınmacılar, kısa süreli vizeleri olanlar, yasal olarak giriş yapmış ancak vizelerini yenilememiş belgesiz göçmenler, çalışma veya öğrenci vizesine sahip olanlar, Türkiye Cumhuriyeti vatandaşları ile evli olup oturum izni alanlar gibi çeşitli göçmen statülerine sahiptir. Pek çok Afrikalı, işgücü piyasasına ve topluma erişim nedeniyle İstanbul'da yaşarken, diğerleri İçişleri Bakanlığı Göç İdaresi Genel Müdürlüğü tarafından yönlendirilen uydu şehirlerine yerleştirilmektedir. İstanbul'daki Afrikalı göçmenler ağırlıklı olarak Beyoğlu ilçesi- Tarlabaşı ve Dolapdere- ilçelerinde, Kumkapı ve Yenikapı ilçelerinde ve Şişli ilçesindeKurtuluş- ve diğer semtlerde ikamet etmektedir (Şaul, 2013). Bu semtlerin

\footnotetext{
2 “Türkiye'deki Afrikalılar, yerel halk üzerinde kalıcı bir etki bırakıyor”, Anadolu Haber Ajansı, 11.12.2017, https://www.aa.com.tr/en/africa/africans-in-turkey-leave-lasting-impression-on-locals/1001490. (Erişim tarihi: 05 Nisan 2019).
} 
çevresinde sosyal alanlarını da oluşturmuşlardır. Birçok farklı ülkeden gelen göçmenler bu semtlere yerleşmişlerdir. Dolayısıyla göçmen çeşitliliği nedeniyle hem çok kültürlü bir kimlik oluşmuştur hem de göçmenlerin birbirleri ile etkileşimleri az olduğu için izole bir ortamın varlığından da söz edilebilir. Farklı ülkelerden gelen göçmenler Kumkapı'nın çeşitli mahallelerinde sosyal alanlar oluşturmuşlardır ve bu sosyal alanlarda kültürel etkileşim sınırlıdır.

İstanbul'da farklı sektörlerde çalışan Afrikalıların büyük bir kısmı geçimini tekstil atölyelerinde çalışarak sağlamaktadır (Şaul, 2013). Bazı Afrikalı göçmenler, İstanbul'dan aldıkları tekstil ürünlerini kendi ülkelerindeki toptancılara göndererek menşe ülkeleri ile iş üzerinden ilişkilerini devam ettirmektedirler. Kargo ofislerinin işletmeciliğini yapan Afrikalı göçmenler de vardır. Yenikapı, Kumkapı civarında kargo şirketlerinde çalışan Afrikalıların bu işletmeleri Afrikalı göçmenler için sadece bir geçim kaynağı değil aynı zamanda ülkelerin ekonomisine de katkı sağlayan önemli bir ticaret kapısı olma niteliğini taşımaktadır. Bu iş kolunun yanı sıra restoran, kafe ve kuaför salonu işletmeciliği rolünü üstlenen ve hizmet sektöründe çalışan Afrikalı göçmenlerin sayısı da oldukça fazladır. iş alanları Afrikalılar için ekonomik kazanımın yani sıra sosyalleştikleri ve kültürel pratiklerini devam ettirdikleri mekanlar olma özelliğini de taşımaktadır. Sosyal ağların oluştuğu ve devam ettiği diğer önemli alan ise kiliselerdir. Araştırma kapsamında ziyaret edilen Uganda ve Demokratik Kongo Cumhuriyeti'nden gelen Afrikalıların kiliseleri sadece ibadet ettikleri yerler değil aynı zamanda sosyal ağlar oluşturdukları toplum merkezleri olarak da işlev görmektedir. Apartman daireleri ve depolarda işlev gören kiliseler Afrikalı göçmenlerin her pazar günü dini ritüellerini devam ettirmek için bir araya geldikleri, birbirlerinin sorunların dinledikleri, birbirlerine destek oldukları, bilgi alışverişi yaptıkları bir ‘sosyal alan' görevi de görmektedir.

Afrikalı göçmenlerin İstanbul'da yerleștikleri semtlerde oluşturdukları sosyal alanlar, sadece bir araya geldikleri ve sosyalleştikleri mekanlar değildir. Aynı zamanda, Afrika yemeklerinin pişirildiği restoranlarda ya da Afrika müziklerinin çalındığı gece kulüplerindeki kültürel tüketim pratikleri ile ulus ötesi bağlar da kurmaktadırlar (Faist, 2003). Çalıştıkları iş alanları, Afrikalı göçmenlerin hem göç alan toplum ile sosyal ilişkilerini güçlendirirken hem de entegrasyon süreçlerinde önemli bir rol oynamaktadır. Bunların yanı sıra kendi kurdukları işletmeler ile hem göç ettikleri ülkenin hem de kendi ülkelerinin ekonomisine katkıda bulunmaktadır.

Tarlabaşı, Kumkapı, Yenikapı ve civarındaki Afrikalı göçmenlerin işlettiği restoranlar da yasal statü elde etmiş olan Afrikalı göçmenler tarafından işletilmektedir. Sokak aralarında görünür olmayan apartman dairesi restoranların varlığı, sadece Afrikalı göçmenler tarafından bilinmektedir. Evi anımsatan bu restoranlar, Afrikalı göçmenler için sadece ülkelerinin yemeklerini yedikleri sosyal bir mekân değildir. Aynı zamanda bir araya geldikleri, birbirlerinin sorunlarını dinledikleri, dayanışma ilişkilerinin kurulduğu sosyal alanlardır. Diğer göçmen 
gruplarının işlettiği restoranlardan farklı olarak Afrikalı göçmenlerin işlettiği restoranlar, onların göç alan toplum ile sosyal köprüler kurmalarına yardımcı olmamaktadır. Göç alan toplumun bireylerinden restoranına gelenlerin sadece maliyeciler olduğunu dile getiren bir restoran işletmecisi, onların da dil bariyeri nedeniyle kendileri ile iletişime girmediklerini söylemiştir. Restoranlar, Afrikalı göçmenler için önemli bir gelir kaynağıdır. Aynı zamanda, bu mekanlar bir araya geldikleri, sosyalleştikleri mekanlar oldukları için de onlar için önem taşımaktadır. Böylelikle bu mekanlar grup içi sosyal ağların ve dayanışmanın oluşmasına da zemin sunmaktadır. Grup içi sosyal ağlar ve dayanışma sayesinde isstanbul'a yeni gelen Afrikalı göçmenler, öncelikle bu restoranlarda çalışmaktadırlar. Çalıştıkları süre içinde geliştirdikleri sosyal ağlar ile ileride başka iş alanlarında çalışma imkânı bulmaktadırlar. Afrikalı göçmenlerin aktif olarak yer aldığı diğer bir iş alanı ise gece kulübü işletmeciliğidir. Özellikle İstiklal Caddesi ve civarında Afrikalıların işlettikleri gece kulüpleri, gittikleri diğer mekanlara göre çok daha görünür yerlerdedir. Fakat bu mekanlar da göç alan toplum tarafından tercih edilmediği için gece kulüpleri üzerinden sosyal köprülerin kurulması da epey zor olmaktadır.

\section{İstanbul'daki Afrikalı Göçmenlerin Gündelik Irkçılık Deneyimleri}

İstanbul'daki Afrikalı göçmenlere yönelik gündelik yaşamda belirgin olan klişeler, önyargılar ve ayrımcılık, onların entegrasyon süreçlerinin önündeki en önemli engellerden birisidir (Coşkun, 2016). Görüşülen Afrikalı göçmenlerin çoğu, ayrımcı davranışların ve ırkçılığın Türkiye'de yeni bir yaşam inşa etmenin önünde engel oluşturduğunu belirtmiştir. Tekstil atölyesinde çalışan Ugandalı bir kadın, Türkiye'de karşılaştığı zorluklardan bahsederken ırkçılığın yeni bir yaşam kurması önündeki en temel engellerden biri olduğunu şu cümlelerle aktarmaktadır:

"Çok az para kazanıyorum ama uzun saatler çalışıyorum. Çoğumuz tekstil atölyelerinde köle gibi çalışıyoruz. Bu işi mecburiyetten yapıyoruz. Birlikte çalıştığımız Türkler bize çok kötü davranıyorlar. Bazen yemek vermiyorlar ya da yemek artıklarını veriyorlar. Birçok Afrikalı kadın patronlarının cinsel tacizine maruz kalıyor" (33 yaşında, Ugandalı, kadın, Kumkapı).

Yukarıdaki alıntıda, Ugandalı kadın hem yapısal hem de gündelik ırkçıık deneyimlerinden bahsediyor. Fox'un da belirttiği gibi "ırkçılık sosyal bir uygulamadır" ve yapısal olanın gündelik olana yansımasıdır. Irkçılığa sadece göçmen olmalarından dolayı değil ten renklerinden dolayı da maruz kaldıklarını söyleyen çoğu Afrikalı göçmen özellikle sokakta yürürken ya da toplu taşıma araçlarında bu durumu deneyimlediklerini şu sözlerle söylediler:

"Bazı yerlerde güvenlik yok. Bazı insanlar sadece siyah olduğumuz için kötü davranıyorlar” (37 yaşında, Nijeryalı, kadın, Kumkapı).

"Bazıları bizi köle gibi çalıştırıyor, bazıları ev kiralamıyor. Bunların hepsi siyah olduğumuz için bize yapılıyor. Çoğu zaman polis durduk yere bizi sokakta durdurup kimlik soruyor. Burada yaşayan diğer 
göçmenlere bu şekilde davranmıyorlar. Bunları sadece göçmen olduğumuz için değil siyah olduğumuz için yaşıyoruz" (28 yaşında, Nijeryalı, kadın, Kumkapı).

“Otobüste, metroda, sokakta ırkçılığa maruz kalıyoruz. Bazen muz atıyorlar, bazen 'zenci' diye bağırıyorlar" (25 yaşında, Ganalı, erkek, Tarlabaşı).

“Irkçılığa maruz kaldım. Sokakta yürürken Türkçe 'kokuyordur' dediler. Bu kelimeyi ilk duyduğum zaman anlamını bilmiyordum ama negatif bir şey olduğunu tahmin ettim. Daha sonra anlamını öğrendim. Ten rengimizden dolayı bunu söylüyorlar. Bazen de yürürken göz göze gelmiyorlar, bakmıyorlar. Bunlar çok üzücü. Bu yüzden burada yaşamak, Türklerle arkadaşlık yapmak çok zor. Ben Avrupa'ya gitmek istiyorum” (22 yaşında, Ugandalı, erkek, Tarlabaşı).

Gündelik hayatta ırkçılığın yaşanması, göç edilen toplumda yaşamı zorlaştııırken Avrupa'ya göç etme düşüncesini de beraberinde getirmektedir. Göçmenler ve göç alan toplum bireyleri arasındaki ilişkiler, göçmenlerin göç alan topluma katılımı ve sosyal uyum için önemli bir unsurdur (Ager ve Strang 2004, 2008; Dahinden 2013; Grzymala-Kazlowska 2015; Sturgis vd. 2014). İşyerinde, sokakta ve mahallede olmak üzere günlük yaşamda ırkçılı̆̆ın yaşanması, göç alan

240 toplum bireyleri ile iletișim kurma sürecini de engellemektedir. Afrikalı göçmenlerin işgücü piyasası ve sosyo-kültürel ortamdan dışlanması, onların günlük yaşamdaki görünürlüğüne ortak bir tepkidir ve benzer tepkiler Avrupa'daki Romanlar için de gösterilmektedir (Fekete 2014; Goodman ve Rowe 2014). Görüşülen Afrikalı göçmenlerin çoğu ayrımcı davranışların ve ırkçılı̆̆ın Türkiye'de yeni bir yaşam inşa etmenin önünde engel oluşturduğunu söylediler:

"Çok fazla çalışıyorum, ancak yeterli para kazanamıyorum. Bizimle (Afrikalılarla) aynı işi yapan Türkler bizden daha az çalışıyorlar ama daha çok para kazanıyorlar. Biz ise daha çok çalışıp daha az para alıyoruz. Bence bu ayrımcılık, ırkçılık” (31 yaşında, Ugandalı, erkek, Yenikapı).

"Uganda'da ticaret ile uğraşıyordum. Buraya gelince aynı işi yapmaya devam ettim. Buradan aldığım ürünleri Uganda'ya gönderiyorum. Dört yıl önce Türkiye’ye geldim. İlk geldiğim zaman bir arkadaşımın yardımıyla "çabuk çabuk" ${ }^{3}$ işinde yani tekstil atölyesinde çalıştım. Çalışma koşulları çok zordu. Çoğu zaman maaşımızı alamıyorduk. İş yerinde ırkçılık vardı. Patrondan ve isçilerden ırkçılık gördüm. O işi yapan bazı arkadaşlarım hala ırkçılığa maruz kalıyorlar. Ev kiralamak istediğimiz zaman da siyah olduğumuz için bize ev vermiyorlar" (41 yaşında, Ugandalı, erkek, Dolapdere).

\footnotetext{
3 "Çabuk çabuk" tasviri Afrikalı göçmenlerin tekstil atölyelerinde çalışıken patronlarından en çok duyduklar kelimedir ve bu yüzden de işlerini tanımlamak için bu kelimeyi kullanmaktadırlar.
} 
Yukarıdaki alıntılar, Afrikalı göçmenlerin özellikle çalışma ortamındaki deneyimlerine dayanmaktadır. Çalışma koşullarının zorluğunun yanı sıra iş yerindeki ayrımcılığın Türkiyeli isçiler ile Afrikalı işçilerin aldıkları ücret farkından çalışma saatlerine kadar her alanda hissedildiğini "bu ırkçılık", "ırkçılığa maruz kalıyorlar” ifadelerini kullanarak maruz kaldıkları durumun ırkçılık olduğunun farkında olduklarını da belirtmişlerdir. Essed'in (1991) araştırmasında da vurgulandığı gibi yapısal güç ilişkilerinin gündelik hayatta deneyimlenmesi ile oluşan ırkçılık, bireylerin deneyimlerinden bahsederken ırkçוlık kelimesini kullanmışlar yani maruz kaldıkları davranışın ırkçıık olduğunun farkındadırlar. Aşağıdaki alıntılar gündelik ırkçılık ile kurumsal ırkçılığın iç içe geçtiği deneyimlerden bahsetmektedir:

“Türkiye’ye ilk geldiğim zaman "çabuk çabuk" işine girdim ve beş yıl boyunca çalıştım. Bazen maaşımı alamadım. İsteyince de 'polise haber verdik gelip seni alacaklar' diye tehdit ediyorlardı. O zamanlar geçerli vizem, çalışma iznim yoktu ve bunu biliyorlardı" (35 yaşında, Kongolu, erkek, Yenikapı).

"Ben bizzat ırkçılık yaşamadım ama arkadaşlarım yaşadı. Türkler, sokakta saat satan iki arkadaşıma 'burada ne işiniz var, ülkenize dönün' demişler. Afrikalıların en büyük sorunu belgesiz olmak ve ırkçılık” (28 yaşında, Senegalli, erkek, Yenikapı).

“iş yerinde, bana para vermediler. Sokakta, polis beni dövdü” (35 yaşında, Nijeryalı, erkek, Yenikapı).

"Sokakta ayrımcılık hissettim. Belki dil engeli yüzündendir, bilmiyorum. İş yerinde bazı problemlerim vardı. Çok çalışıyorum ama daha az para kazanıyorum. Türkçe konuşamadığımda bana kötü davranıyorlar" (25 yaşında, Ganalı, erkek, Kumkapı).

"Türk halkı ırkçı. Bize çok kötü davranıyorlar. Çalışıyoruz maaşımızı vermiyorlar, sokakta itip kakıyorlar. Ev kiralamıorlar. Bize insan gibi davranmıyorlar" (28 yaşında, Kongolu, erkek, Dolapdere).

Afrikalı göçmenlerin deneyimleri, göç alan toplum bireyleri ile etkileşime girdikleri hemen hemen her alanda iş yerinde, sokakta, ırkçılığa ve hatta kurumsal ırkçılık örneği olarak polisin Afrikalı göçmenlere yönelik ayrımcı tutum ve davranışlarına maruz kaldıklarını göstermektedir. Afrikalı göçmenlerin gündelik hayatın her alanında yaşadığı sorunların benzer olduğunu söyleyen Nijeryalı göçmen İstanbul'da bulunduğu süre içinde maruz kaldığı ayrımcılık ve ırkçılığın tüm Afrikalı göçmenler tarafından deneyimlendiğini şu sözlerle dile getirdi:

"Ev kiralamak istediğim zaman siyah olduğum için kiralayamadım; Türkiyeliler ile aynı işi yapıyorum ama siyah olduğum için daha az ücret alıyorum. Bunlar sadece benim yaşadığım şeyler değil. Birçok 
Afrikalı göçmen Türkiye'de benzer deneyimleri yaşıyor” (27 yaşında, Nijeryalı, erkek, Dolapdere).

Afrikalıların gündelik hayatın her alanında ırkçılığa maruz kaldığını söyleyen papaz, kilisenin de ırkçı saldırılardan nasibini aldığını şu sözlerde dile getirdi:

"Mahallede yaşayan insanlar, kilisemize saldırdılar. Durumu polise söyledik ama soruşturma yapılmadı. Polis hiçbir şey yapmadı. Ben iki yıldır bu kilisenin papazı olarak görev yapıyorum ve iki yıl boyunca mahallede yaşayan insanlar birçok kere kilisemize saldırdılar. Bu yüzden endişeliyiz ve korkuyoruz. Kiliselerimizi kaybetmek istemiyoruz çünkü insanlar burada sadece ibadet etmiyorlar. Afrikalı göçmenlerin çoğu için kiliseler kendilerini güvende ve iyi hissettikleri mekanlar" (45 yaşında, Ugandalı, erkek, Dolapdere).

Afrikalı göçmenler ve göç alan toplum bireyleri arasındaki günlük etkileşimlere yansıyan güç ilişkileri, günlük ırkçılığın inşası için temel dayanaklardan biridir. Yerel halkla Suriyeli mülteciler arasındaki günlük etkileşimlere yansıyan güç ilişkileri, günlük ırkçılığın inşası için temel dayanaklardan biridir. Göç alan toplum tarafından yeniden yaratılan güç dinamikleri, Afrikalı göçmenlerin günlük yaşamda maruz kaldıkları yapısal eşitsizliklere neden olmaktadır:

“Dolapdere'de yaşıyorum, 'çabuk çabuk' işinde çalışıyorum. Buradaki yaşamımdan memnun değilim çünkü insan gibi davranmıyorlar. Mesela, iş yerinde Türkler yemek yedikten sonra bizi çağırıyorlar çünkü artık yemekleri bize yedirtiyorlar. Siyah olduğumuz için bizden daha yüksek ev kirası alıyorlar. Hastaneye gittiğimizde siyah olduğumuz için para istiyorlar. Burada hiçbir hakkımız yok. Sokakta, iş yerinde, hastanede yani her yerde ırkçılığa maruz kalıyoruz" (32 yaşında, Ugandalı, kadın, Dolapdere).

Essed (1991) tarafından belirtildiği gibi, ırkçılık çeşitli ilişkiler ve pratikler üzerinden yaşanmakta, günlük uygulamalarla sistematik olarak yaratılmakta, yeniden oluşmakta ve güçlendirilmektedir. Afrikalı kadın göçmenlerin deneyimleri ise erkeklerin deneyimlerinden farklılaşmaktadır. Afrikalı kadın göçmenler erkeklere kıyasla ırkçılı̆ın yanı sıra cinsel tacize de maruz kaldıklarını şu sözlerle dile getirdiler:

"Sokakta bize (Afrikalı kadınlara) dokunmaya çalışıyorlar. Tenimizin renginden dolayı dönüp dönüp bakıyorlar. Siyahlar için her şey çok daha pahalı: kira, sağlığa erişim. Taksisine bindiğim bir şoför bana âşık olduğunu söyledi, arabayı kenara çekip bana tokat attı, dokundu. Sonra taksiden inip kaçtım. Kaçmasaydım belki de bana tecavüz edecekti. Polise de şikâyet edemedim çünkü o zaman vizem yoktu. 
Çok üzüldüm. Irkçılık, taciz her şeyi yaşadım burada" (31 yaşında, Ugandalı, kadın, Kurtuluş).

Görüşülen başka bir Ugandalı kadın, Türkiye'de siyahi kadın olmanın zorluklarını kendi deneyimleri üzerinden şu sözlerle dile getirdi:

“Türkiye'de tüm siyah kadınların seks işçisi olduğu algısı var. Bu yüzden çoğu Afrikalı kadın iş yerinde ve sokakta cinsel tacize maruz kalıyor. Tekstil atölyelerinde işverenlerin çoğu, Afrikalı kadın işçilere tecavüz girişiminde bulunuyor. Cinsel ilişkiyi reddettikleri zaman işten atılmakla tehdit ediliyorlar. Bunu birçok Afrikalı kadından duydum. Sokakta sırf siyah kadın olduğumuz için bize dokunmaya çalışıyorlar çünkü bizi seks işçisi sanıyorlar” (30 yaşında, Ugandalı, kadın, Kurtuluş).

Yukarıdaki alıntılarda belirtildiği gibi Ugandalı kadınların anlattıkları, Türkiye'de yaşayan birçok Afrikalı kadının deneyimlerini de yansıtıyor. Ten renginden kaynaklanan ırkçılığın yanı sıra Afrikalı kadın göçmenler kadın oldukları için de cinsel tacizle ve cinsiyetçi söylemlerle karşılaşıyorlar, hatta tecavüze uğrama tehlikesi yașıyorlar. Coşkun (2016)'un da belirttiği gibi Ugandalı göçmen kadınların çoğu iş yerlerinde göçmen olmalarından dolayı ırkçılığa ve kadın olmalarından dolayı da cinsel tacize maruz kalmaktadır. Ugandalı kadınların yanı sıra Nijeryalı kadınlar da gündelik hayatta cinsel tacize uğruyorlar, ırkçılı̆a maruz kalıyorlar:

"Sokakta yürürken laf atıyorlar, dokunmaya çalışıyorlar, taciz ediyorlar. Türklerin çoğu ırkç”" (28 yaşında, Nijeryalı, kadın, Tarlabaşı).

"Her yerde, işte, sokakta, pazarda, mahallede ayrımcılık hissediyorum. Örneğin, iş yerinde patron "çabuk çabuk" diyor; benimle yatmak istedi. Kabul etmedim ve çok fazla sıkıntım vardı, acı çektim. İşimden ayrıldım. Şu anda çalıştığım dükkânda da çok çalışıp az para alıyorum" (31 yaşında, Nijeryalı, kadın, Kumkapı).

Coşkun (2016: 92)'un vurguladığı gibi Afrikalı kadın göçmenler de diğer belgesiz göçmenler gibi zor şartlar altında çalışmakta ve belgesiz oldukları için haklarını savunacakları bir mecra yoktur ve bu durum "özellikle de toplumsal cinsiyet, etnisite ve göçün karmaşık ilişkilerinin kesişim noktalarında bulunan Sahra-Altı Afrika ülkelerden gelen kadın göçmenleri çok daha kırılgan bir konuma sokmaktadır".

Görüşülen Afrikalı göçmenlerin büyük bir bölümü göç alan toplumun bireyleri tarafından iş yerinde, sokakta ve toplu taşıma araçlarında maruz kaldıkları ayrımcılık ve ırkçılık nedeniyle kendilerini güvende hissetmediklerini söylediler. Çoğu zaman Afrikalılara yönelik ırkçılık saldırıya da dönüşebiliyor: 
"Buraya geldiğimde dövüldüm. Bana hakaret ediyorlar, kötü sözler söylüyorlar. Beni kötüye kullanıyorlar. Kullandıkları bu kelimelerin dilini ve anlamların bilmiyorum, ama negatif kelimeler olduklarını tahmin ediyorum" (27 yaşında, Senegalli, erkek, Yenikapı).

Göçmenler ve göç alan toplum bireyleri arasında iletişimin kurulduğu bir ortam gerçekleşmediğinde ve gündelik ırkçlık şiddet olaylarına dönüştüğünde, Afrikalı göçmenler bireysel güvenliklerinden endişe duyuyorlar. Gündelik yaşamda maruz kaldıkları ırkçıı ile mücadele etme stratejileri ise sosyal alanlarında (restoranları, kiliseler, kargo işletmeleri, gece kulüpleri) göç alan toplumdan izole bir yaşam sürmek:

“Kumkapı'da yaşıyorum ve burada kendimi güvende hissetmiyorum. Özellikle hava karardıktan sonra burada yürümek tehlikeli olabiliyor. Burada hırsızlığa ve ırkçı saldırılara maruz kalıyoruz. Türklerden uzakta olunca kendimizi güvende hissediyoruz. Bu yüzden restoranlarımızda, iş yerlerimizde bir arada oluyoruz. Ancak bu şekilde var olabiliyoruz. Bu aslında kendimizi ırkçı saldırılardan koruma stratejisi. Geçen sene bir arkadaşımız burada öldürüldü. Bakın fotoğrafını buraya astık. Benzer şeyleri yaşamak istemiyoruz. Bu yüzden kendimize izole bir yaşam kurduk" (29 yaşında, Nijeryalı, erkek, Kumkapı).

Kilisenin papazı, kilisenin sadece ibadet yeri olmadığını aynı zamanda topluluk arası bağların güçlendiği önemli bir sosyal alan oluşturduğunu şu sözlerle dile getirmiştir:

"Ugandalılar, her pazar günü kiliseye gelerek sadece ibadet etmiyorlar aynı zamanda diğer Ugandalılar ile bir araya geliyorlar, sorunlarını dile getiriyorlar, birbirlerini dinliyorlar, aralarındaki sosyal ağlar güçleniyor, birbirlerine destek oluyorlar ve ülkelerinde devam ettirdikleri ritüelleri Türkiye'de de devam ettirerek bağlarını güçlendiriyorlar” (45 yaşında, Ugandalı, erkek, Dolapdere).

Kiliselerin yanı sıra futbol sahaları da birçok Afrikalı genç için de boş zamanlarını değerlendirdikleri, sosyal ağlar kurdukları hem de bazıları için potansiyel geçim kaynağı olan önemli bir alandır.

Kiliseler, restoranlar, işletmeler ve benzeri sosyal alanlar Afrikalı göçmenlerin ulus ötesi bağlar kurmalarını da sağlamaktadır. Kiliseler ve benzeri dini mekanlar hemen hemen tüm Afrikalı göçmenler için sadece ibadet ettikleri mekanlar değil; aynı zamanda sosyal ağların oluştuğu, gündelik hayatın izole halinden uzaklaştıkları, topluluk içinde duygusal bağlar kurdukları, kendilerini güvende hissettikleri, dayanışmanın hâkim olduğu sosyal alanları temsil etmektedir. Aynı zamanda da göç ettikleri ülkede yeni bir hayat kurma sürecinde en çok yardımcı olan etmenlerin arasında yer almaktadır. 
Afrikalı göçmenlerin deneyimleri gündelik ırkçılığın bir örneği olarak tanımlanabilir, çünkü bu deneyimler günlük yaşamda genelleştirilebilen, tekrarlanabilen ve toplumsallaştırılmış tutumları içeren deneyimlerdir. Ayrıca göç alan toplumla etkileşimleri de sosyal tabakalaşmadan etkilenmektedir. Görüşülen Afrikalı göçmenlerin çoğu, göç alan toplum ile ilişkilerine değindiklerinde "ırkçı", "ırkçılık" ve "ırkçı saldırılar” kelimelerini doğrudan kullanmışlardır. Gündelik hayatta ırkçılığa maruz kaldıklarını ve bu deneyimlerinin Türkiye'deki yaşamlarını zorlaştırdığını belirtmişlerdir. Başka bir deyişle, ırkçıık Türkiye'deki yerleşim sürecinde bir engel oluşturmaktadır.

\section{Sonuç}

Afrikalı göçmenlere yönelik gündelik ırkçılık toplumda var olan yapısal eşitsizliklerin gündelik pratiklerle güçlendirilmesi ile oluşmaktadır. Bu, ampirik verilerle desteklenmiştir. Araştırma kapsamında görüşülen Afrikalı göçmenler, göç alan toplum bireyleri ile ilişkilerinden bahsettiklerinde, özellikle işyerinde, sokaklarda ve mahallelerde kurdukları etkileşimlere değinerek açıkça ırkçılığa maruz kaldıklarını ve bu durumun üstesinden gelmek için daha izole bir şekilde yaşadıklarını ya da Avrupa'ya taşınmayı düşündüklerini belirttiler. Birçok katılımcının ırkçılık deneyimleri, gündelik yaşamda kendini gösteren yapısal eşitsizliklere neden olan güç dinamiklerini temel alarak inşa edilmiştir. Ten renginden kaynaklanan ırkçılığın yanı sıra Afrikalı erkeklerden farklı olarak cinsel tacize maruz kaldıklarını hatta tecavüze uğrama tehlikesi yaşadıklarını söyleyen Afrikalı kadınların deneyimlerinin toplumsal cinsiyet rolleri ile ilişkili olduğunu göstermektedir. Afrikalı göçmenlerin deneyimleri, genelleștirilebilen, tekrarlanabilen, toplumsallaştırılmış tutumları içerdiği ve göç alan toplum bireyleri ile etkileşimlerinin toplumdaki sosyal tabakalaşmalardan etkilendiği için gündelik ırkçılık örnekleri olarak tanımlanabilir. Ayrımcılık ve önyargılar, göçün topluma yönelik sosyo-kültürel bir tehdit olduğu algısına da dayanıyor (Sole and Parella 2003; Ben-Eliezer 2008).

Ampirik verilerle desteklendiği gibi, Afrikalı göçmenlere yönelik ırkçılık sosyo-ekonomik, kültürel ve politik faktörlerden etkilenen güç dinamikleri içinde yeniden yaratılmakta ve günlük rutinlerdeki toplumsal ilişkilere nüfuz etmektedir. Araştırma bulguları, "gündelik ırkçılığın" yapısal eşitsizlikler ile güçlenen, gündelik yaşamın her alanında görülen güç ilişkileri tarafından şekillendiği savını desteklemektedir (Essed 2002; Hallgren 2005). Afrikalı göçmenlerin gündelik hayatta maruz kaldıkları ırkçılık, güç ilişkilerinin sistematik bir şekilde yapılandırımasının yani sistematik ırkçılığın bir sonucudur. Afrikalı göçmenlerin aynı işi yapmalarına rağmen göç alan toplum bireylerinden daha uzun saatler çalışmaları, onlardan daha az ücret almaları, ev kiralayamamaları, eğitime ve sağlık hizmetlerine erişimlerinin sınırlı olması sistematik ırkçılığın sonucudur. Sistematik ırkçılık göçmenler ve göç alan toplum bireyleri arasındaki ilişkiye de yansıyarak günlük yaşamda kendisini göstermektedir. Essed (1991) "gündelik ırkçılık” kavramını açıklarken kişisel deneyimlere yoğunlaşmıştır ve ırkçılığı üreten 
ve pekiştiren ekonomik, sosyal, politik veya kültürel yapılara ve kurumlara değinmemiştir. Ampirik verilerin de desteklediği gibi Afrikalı göçmenlerin gündelik ırkçılık deneyimleri, sistematik ırkçılığın etkilerini taşımaktadır. Gelecekte yapılacak olan çalışmalar, gündelik ırkçılık kavramını açıklarken mezo ve makro düzeylere de odaklanarak sistematik ırkçılık ile ilişkisini araştırabilir.

\section{Notlar}

1 "Türkiye'deki Afrikalılar, yerel halk üzerinde kalıcı bir etki bırakıyor", Anadolu Haber Ajansı, 11.12.2017, https://www.aa.com.tr/en/africa/africans-inturkey-leave-lasting-impression-on-locals/1001490. (Erişim tarihi: 05 Nisan 2019).

2 “Çabuk çabuk" tasviri Afrikalı göçmenlerin tekstil atölyelerinde çalışırken patronlarından en çok duydukları kelimedir ve bu yüzden de işlerini tanımlamak için bu kelimeyi kullanmaktadırlar.

\section{Kaynakça}

Ager, A. ve Strang, A. (2004) “Indicators of Integration: Final Report", Home Office Development and Practice Report 28, London: Home Office.

Ager, A. ve Strang, A. (2008) 'Understanding Integration: A Conceptual Framework', Journal of Refugee Studies 21(2): 166-191.

Back, L. (1993) 'Race, identity and nation within an adolescent community in South London', Journal of Ethnic and Migration Studies, vol. 19, no. 2, pp.

Baird, Theodore. "The missing migration component of Turkey-Africa relations."Open Democracy (2011). https://www.opendemocracy.net/theodore-baird/missing-migrationcomponent-of-turkey-africa-relations.

Banton, M. (1979) 'Analytical and folk concepts of race and ethnicity', Ethnic and Racial Studies, vol. 2, no. 2, pp. 127-138.

Ben-Eliezer, U. (2008) "Multicultural society and everyday cultural racism: second generation of Ethiopian Jews in Israel's 'crisis of modernization", Ethnic and Racial Studies, vol. 31, no. 5, pp. 935- 961.

Brewer, K. T. ve Yükseler, D. (2006), A Survey of African Migrants and Asylum Seekers in İstanbul (İstanbul: Migration Research Program at the Koç University, MiReKoç Research Projects 2005-2006).

Brubaker, R. (1990) 'Immigration, Citizenship, and the Nation-State in France and Germany: A Comparative Historical Analysis', International Sociology, vol. 5, no. 4, pp. 79-407.

Castles, S. (1993) 'Migrations and Minorities in Europe: Perspectives for the 1990s: Eleven Hypotheses', in John Wrench and John Solomos (eds.), Racism and Migration in Western Europe, London: Berg Publishers, pp. 17- 35.

Castles, S. ve Kosack, G. (1973) Immigrant workers and class structure in Western Europe, Oxford: UK, Oxford University Press.

Cornell, E. S.; Hartmann, D. (2007) Ethnicity and Race: Making Identities in a Changing World, second edition, Thousand Oaks, CA: Pine Forge Press. 
Coskun, E. (2016) “Türkiye'nin göç rejiminde toplumsal cinsiyet faktörü: Ugandalı göçmen kadınlar örneği” Fe Dergi 8, no. 1 (2016), 91-104.

Dahinden, J. (2013) 'Cities, Migrant Incorporation, and Ethnicity: A Network perspective on boundary work, Journal of International Migration and Integration, vol.14, no.1, pp. 39-60.

De Clerk, H. M. (2013) "Sub-Saharan African Migrants in Turkey: A Case Study on Senegalese Migrants in Istanbul" SBF Journal 68, no.1 (2013):39-58. http://dergiler.ankara.edu.tr/dergiler/42/1782/18820.pdf.

Erel, U.; Murji, K. ve Nahaboo, Z. (2016) Understanding the contemporary racemigration nexus, Ethnic and Racial Studies, vol. 39, no. 8, pp.1339-1360.

Essed, P. (1991) Understanding Everyday Racism: An Interdisciplinary Theory, vol 2. Newbury Park, CA: Sage.

Essed, P. (1993) The Politics of Marginal Inclusion: Racism in an Organisational Context, in John Wrench and John Solomos (eds.), Racism and Migration in Western Europe, London: Berg Publishers, pp.143-177.

Essed, P. (2002) 'Everyday Racism: A New Approach to the Study of Racism', in Philomena Essed and David Theo Goldberg (eds.) Race Critical Theories: Text and Context, pp. 176-94.

Faist, T. (2003) Uluslararası göç ve ulusaşırı toplumsal alanlar, (çev. Azat Zana Gündoğan, Can Nacar), Bağlam yay., 486 sayfa.

Fekete, L. (2009) A Suitable Enemy: Racism, Migration and Islamophobia in Europe, London: Pluto.

Fekete, L. (2014) 'Europe against the Roma', Race and Class, vol. 55, no.3, pp. 6070.

Giddens, A. (1981) "Agency, institution, and time-space analysis", in Karin Knoor Cetina and Aaron Victor Cicourel (eds.) Advances in social theory and methodology: Toward an integration of micro-and macro-sociologies, pp. 161-174.

Gilroy, P. (1987) ‘There Ain't No Black in Union Jack': The Cultural Politics of Race and Nation, London: Hutchinson.

Goldberg, D. T. (1990) 'The social formation of racist discourse', in David Theo Goldberg (ed.) Anatomy of Racism, Minneapolis, MN: Univ. Minnesota Press, pp. 295-318.

Goldberg, D. T. (2005) 'Racial Americanization', in Karim Murji and John Solomos (eds.) Racialization: Studies in theory and practice, Oxford: UK, Oxford University Press, pp. 87-102.

Goodman, S. ve Rowe, L. (2014) 'Maybe it is prejudice ... But it is NOT racism': Negotiating racism in discussion forums about Gypsies'. Discourse \& Society, Vol. 25, pp. 32-46.

Grzymala-Kazlowska, A. (2015) "The role of different forms of bridging capital for immigrant adaptation and upward mobility. The case of Ukrainian and Vietnamese immigrants settled in Poland", Ethnicities, vol.15, no.3, pp.46090. 
Hallgren, C. (2005) 'Working harder to be the same': everyday racism among young men and women in Sweden', Race, Ethnicity and Education, vol. 8, no.3, pp.319- 342 .

Miles, R. (1989) Racism, London: Routhledge.

Rex, J. (1973) Race, Colonialism and the City, London: Routledge.

Şaul, M. (2013) "Sahra Altı Afrika Ülkelerinden Türkiye’ye İş Göçü”, Ankara Üniversitesi, SBF Dergisi, Cilt. 68, No. 1, pp. 83-121.

Schuster, L. (2003) 'Common Sense or Racism: The Treatment of Asylum Seekers in Europe', Introduction to Special Issue of Patterns of Prejudice, vol. 37, no.3, pp. 233-55.

Sole, C. ve Parella, S. (2003) 'The labour market and racial discrimination in Spain', Journal of Ethnic and Migration Studies, vol. 29, no.1, pp. 121-140.

Solomos, J. ve Back, L. (2001) 'Conceptualizing Racisms: Social Theory, Politics and Research' in Ellis Cashmore and James Jennings (eds) Racism: Essential Readings, pp. 346-56, London: Sage.

Solomos, J. (1989) Race and Racism in Contemporary Britain, London: Macmillan.

Sturgis, P.; Brunton-Smith, I.; Kuha, J.; Jackson, J. (2014) Ethnic diversity, segregation and the social cohesion of neighbourhoods in London, Ethnic and Racial Studies, vol. 37, no.8, pp.1286-1309.

Özdil, K. (2008) "Creating New Spaces, Claiming Rights. West African Immigrants in Istanbul- Public Istanbul: spaces and spheres of the urban" IOM (2008): 279-298.

Özkan, M. ve Akgün, B. (2010) “Turkey’s Opening to Africa” (November 4, 2010). The Journal of Modern African Studies, Vol. 48, No. 4, pp. 525-546, December 2010. Available at SSRN: https://ssrn.com/abstract=1977545.

Wrench, J. ve Solomos, J. (1993) Racism and migration in Western Europe, Oxford: Berg Publishers.

Vasta, E. (1993) 'Rights and racism in a new country of immigration: The Italian case', in John Wrench and John Solomos (ed.) Racism and Migration in Western Europe, Oxford: Berg Press, pp. 83- 98. 